Ks. Robert Kantor*

Uniwersytet Papieski Jana Pawła II w Krakowie

Wydziat Teologiczny Sekcja w Tarnowie

\title{
DZIAŁALNOŚĆ RADY KAPŁAŃSKIEJ DIECEZJI TARNOWSKIEJ ZA CZASÓW BPA JÓZEFA ŻYCIŃSKIEGO W LATACH 1990-1997
}

Stowa kluczowe

Rada kapłańska, biskup, diecezja tarnowska, bp Życiński

Treść

I. Rada kapłańska w ustawodawstwie kościelnym

1. Ustawodawstwo soborowe i posoborowe do kodyfikacji z 1983 roku

2. Rada kapłańska w Kodeksie Prawa Kanonicznego z 1983 roku

II. Rada kapłańska w diecezji tarnowskiej - początki i okres pasterzowania bpa Józefa Życińskiego

III. Zagadnienia poruszane na spotkaniach Rady kapłańskiej pod przewodnictwem bpa Józefa Życińskiego

1. Sprawy dotyczące życia i posługi kapłanów diecezji tarnowskiej

2. Uświęcenie i religijna formacja wiernych świeckich

3. Przeznaczanie ofiar składanych z racji wykonywania zadań parafialnych i wynagrodzenia duchownych

4. Inne sprawy mające na uwadze dobro Kościoła tarnowskiego

Bp Józef Życiński urząd biskupa tarnowskiego pełnił od 4 listopada 1990 do 14 czerwca 1997 roku, kiedy to został mianowany arcybiskupem, metropolitą lubelskim. Jako biskup tarnowski prowadził diecezję w trudnych latach transformacji ustrojowej. Obecny biskup tarnowski Wiktor Skworc na wieść o śmierci bpa Życińskiego skierował do wiernych diecezjan komunikat, w którym czytamy: „Biskup Józef Życiński w latach pasterzowania wznosił z prezbiterami, osobami

* Ks. Robert Kantor, dr prawa kanonicznego, sędzia audytor w Sądzie Diecezjalnym w Tarnowie, wykładowca prawa kanonicznego na Wydziale Teologicznym Sekcja w Tarnowie UPJPII w Krakowie. 
konsekrowanymi i wiernymi świeckimi Kościół żywy, wizytował i przynaglał diecezjan do angażowania się w dzieło ewangelizacji i podejmowania odpowiedzialności za Kościół"'.

Wśród wielu spraw, jakimi zajmował się bp Józef Życiński, było także przewodniczenie posiedzeniom Rady kapłańskiej. Stąd tytuł niniejszego opracowania, który dotyczy działalności Rady kapłańskiej za czasów kierowania diecezją przez bpa Józefa Życińskiego w latach 1990-1997. W tym celu zostały wykorzystane wybrane sprawozdania z posiedzeń Rady. Zanim jednak zostaną przedstawione konkretne zagadnienia rozpatrywane na spotkaniach Rady kapłańskiej diecezji tarnowskiej, zasadnym będzie ogólne naszkicowanie tej instytucji w ustawodawstwie po Soborze Watykańskim II.

\section{RADA KAPŁAŃSKA W USTAWODAWSTWIE KOŚCIELNYM}

Już w pierwszych wiekach chrześcijaństwa biskup w zarządzaniu swoim Kościołem partykularnym był wspomagany przez kolegium prezbiterów, które stanowiło jego senat ${ }^{2}$. Jednak dopiero Sobór Watykański II i ustawodawstwo posoborowe przyczyniły się do utworzenia Rad kapłańskich.

\section{Ustawodawstwo soborowe i posoborowe do kodyfikacji z 1983 roku}

Sobór Watykański II starał się od samego początku klarownie przedstawić sprawę ustanowienia Rady kapłańskiej. Dekret o posłudze i życiu kapłanów Presbyterorum Ordinis w $\mathrm{nr} 7^{3}$ wskazuje, że Rada kapłańska ma być senatem reprezentującym całe prezbiterium określonego Kościoła partykularnego. Według tego dokumentu soborowego podstawowym zadaniem Rady miało być skuteczne wspieranie biskupa swymi radami w zarządzaniu diecezją. W ten sposób biskup wysłuchuje swoich kapłanów, radzi się ich i rozmawia z nimi o sprawach, które dotyczą potrzeb duszpasterstwa i dobra diecezji. Nawiązuje on także ściślejszy i skuteczniejszy kontakt ze swoimi kapłanami, poznaje ich myśli i potrzeby. Nie chodzi tu o bezpośredni udział Rady kapłańskiej w rządzeniu i kierowaniu diecezją. Ma on być tylko pomocą w kierowaniu diecezją a Rada nie może sama sobie przypisywać władzy rządzenia. Nie jest ona bowiem zespołem osób równych biskupowi. Użycie przez Sobór

1 Bp. W. Skworc, Komunikat Biskupa Tarnowskiego w związu ze śmiercia ks. abpa Józefa Życińskiego, „Currenda” 2 (2011), s. 201.

2 Por. E. Górecki, Rada kapłańska, w: Struktury kolegialne w Kościele partykularnym. Materiaty z ogólnopolskiej konferencji naukowej zorganizowanej przez Stowarzyszenie Kanonistów Polskich, Wydziat Nauk Prawnych TN KUL i Wyższe Seminarium Duchowne w Tarnowie, red. J. Krukowski, T. Rozkrut, Tarnów 2004, s. 84.

3 „Niech (biskupi) mają radę, czyli senat kapłanów, reprezentujących ogół prezbiterów, który dostosowany do dzisiejszych okoliczności i potrzeb w formie i według norm prawnych do określania, mógłby skutecznie wspierać biskupa swymi radami w rządzeniu diecezją”. PO 7. 
wyrażenia suis concilis wyraźnie podkreślało doradczy charakter tej instytucji ${ }^{4}$. Dekret Presbyterorum Ordinis nie podał gotowych rozwiązań dotyczących Rady, ale pokreślił, że budowę i normy działania Rady określi prawo.

Papież Paweł VI w dniu 6 sierpnia 1966 roku promulgował Motu proprio Ecclesiae Sanctae ${ }^{5}$ zawierające przepisy wykonawcze do czterech dekretów soborowych, m.in. do Presbyterorum Ordinis. Pierwszym ważnym ustaleniem, jakie zawiera ten dokument papieski jest nazwanie nowego organu doradczego biskupa diecezjalnego Radą kapłańską - Cosilium Presbyterale. Jest ona tutaj rozumiana jako zebranie, czyli senat kapłanów, reprezentujących ogół prezbiterium. Dokument Ecclesiae Sanctae potwierdził doradczy charakter Rady nakładając na biskupa obowiązek jej wysłuchania w ważniejszych sprawach dotyczących organizacji parafialnej czy uposażeń duchownych.

Odwołując się do dokumentów posoborowych w interesującej nas materii warto wspomnieć o Liście Okólnym Kongregacji ds. Duchowieństwa Presbyteri sacra ${ }^{6}$ dotyczącym Rad kapłańskich. W Liście tym została szerzej potraktowana kwestia reprezentatywności, tzn., że Rada kapłańska powinna reprezentować całe prezbiterium diecezji. Zatem różne posługi kapłańskie, okręgi duszpasterskie i poszczególne generacje kapłanów w miarę możliwości powinny mieć swoich przedstawicieli. Poza tym dokument ten w sposób istotny poszerzał funkcje i zadania Rady kapłańskiej stwierdzając, że tytuł i funkcja senatu biskupa w zarządzie diecezją odnosi się jedynie do Rady kapłańskiej. Rada ta została powołana celem wspomagania biskupa w zarządzaniu diecezją. Reprezentuje ona całe prezbiterium, a zatem jest ustanowiona dla dobra całej diecezji, stąd jej zadania nie mogą być ograniczane tylko do spraw dotyczących życia kapłanów. Ma ona nieść pomoc biskupowi ${ }^{7}$. List Kongregacji ds. Duchowieństwa nazywał Radę kapłańską organem doradczym szczególnego rodzaju, gdyż swoją naturą i sposobem działania przewyższała inne organy doradcze biskupa. Kongregacja w Liście Okólnym nakładała na każdą Radę obowiązek przygotowania własnych statutów.

Zanim przejdę do postanowień kodeksowych w sprawie Rady kapłańskiej, nie można pozostawić bez echa Instrukcji Ecclesiae imago o pasterskim posługiwaniu biskupów z 22 lutego 1973 roku$^{8}$. Dokument ten precyzuje kompetencje Rady kapłańskiej, które zostały ukazane w następującej kolejności:

- sprawy życia kapłańskiego - ważniejsze sprawy dotyczące świętości życia, wiedzy teologicznej oraz innych potrzeb kapłanów;

4 Por. J. Wroceński, Rola i zadania prezbiterium w życiu Kościoła partykularnego, Warszawa 1998, s. 294.

5 Paweł VI, Motu proprio Ecclesiae Sanctae, w: AAS, 58 (1966), s. 757-787.

6 Kongregacja ds. Duchowieństwa, Littere Circulares ad Praesides Conferentiarum Episcopalium de Consiliis Presbyteralibus iuxta placita Congregationis Plenariae die 10 octobris 1969 habitae, w: AAS, 62 (1970), s. 459-465.

7 Por. J. Wroceński, Rola i zadania prezbiterium, dz. cyt., s. 250.

8 Kongregacja ds. Biskupów, Instrukcja Ecclesiae imago z 22 lutego 1973, w: Polskie Prawodawstwo Kościelne, red. E. Sztafrowski, t. 6, z. 1, s. 15-325. 
- uświęcanie i religijna formacja wiernych;

- ogólny zarząd diecezją pod kątem kapłańskiego posługiwania dla dobra całej wspólnoty kościelnej’.

Zadaniem Rady miało być także poszukiwanie wyraźnych i jasno określonych celów działania, wskazywanie metod postępowania i popieranie wszystkiego, co jest niezbędne do osiągnięcia jedności. $Z$ tych wytycznych wynika, że Rada kapłańska powinna się zajmować zasadniczymi kierunkami pracy duszpasterskiej. Instrukcja potwierdziła szczególny charakter Rady kapłańskiej rezerwując jej tytuł i funkcje senatu biskupa w kierowaniu diecezją ${ }^{10}$.

\section{Rada kapłańska w Kodeksie Prawa Kanonicznego z 1983 roku}

Prawodawca kodeksowy przewiduje istnienie w Kościołach partykularnych organów kolegialnych, które stanowią dla biskupa pomoc w wykonywaniu władzy pasterskiej. Kodeks traktuje o Radzie kapłańskiej w kan. 495-501. Kan. $495 \S 1$ KPK podaje definicje Rady kapłańskiej i postanawia: „W każdej diecezji winna być ustanowiona Rada kapłańska, czyli zespół kapłanów, będący jakby senatem biskupa i reprezentującym prezbiterium. Jej zadaniem jest wspieranie biskupa w kierowaniu diecezją, zgodnie z przepisami prawa, ażeby możliwie najbardziej pomnażało się dobro pasterskie powierzonej mu części Ludu Bożego". Kodeks zobowiązuje biskupa do utworzenia w diecezji Rady kapłańskiej i ramowo określa jej strukturę, szczegółowe zaś kwestie pozostawia do ustalenia prawu partykularnemu. Biskup powinien też zadbać o to, by Rada kapłańska przygotowała swój statut zgodny ze wskazaniami Stolicy Apostolskiej i własnej konferencji biskupów. Zakres działalności Rady jest tak szeroki, jak rozległa jest misja pasterska biskupa diecezjalnego. Ks. prof. Mirosław Sitarz twierdzi, iż obowiązek wspierania biskupa przez kapłanów i obowiązek wysłuchania rad kapłanów przez biskupa wynika z partycypacji w tym samym sakramencie i wspólnej misji skierowanej do pomnażania dobra Ludu Bożego ${ }^{11}$.

Rada kapłańska posiada tylko głos doradczy. Jednak prawodawca obliguje biskupa do wysłuchania w ważnych sprawach opinii Rady kapłańskiej:

- przed zwołaniem synodu diecezjalnego (kan. $461 \S 1$ );

- przed wydaniem dekretu o jego zawieszeniu lub rozwiązaniu (Apostolorum Successores, $\mathrm{nr}$ 172);

- przed erygowaniem i znoszeniem parafii lub przed dokonaniem w niej poważnych zmian (kan. $515 \S 2$ );

- przed wydaniem przepisów dotyczących przeznaczenia ofiar składanych z racji wykonywania zadań parafialnych i wynagradzania duchownych (kan. 531);

9 Instrukcja Ecclesiae imago, nr 203, s. 289.

10 Por. J. Wroceński, Rola i zadania prezbiterium, dz. cyt., s. 256.

11 M. Sitarz, Kompetencje organów kolegialnych w Kościele partykularnym, Lublin 2008, s. 67. 
- przed wydaniem decyzji o ustanowieniu w każdej parafii rady duszpasterskiej (kan. $536 \S 1$ );

- przy udzielaniu zezwolenia na budowę nowego kościoła (kan. 1215 § 2);

- przed wydaniem decyzji przeznaczającej kościół do użytku świeckiego (kan. 1222 § 2);

- w sytuacji nałożenia podatku diecezjalnego na prawne osoby publiczne podlegające jego jurysdykcji (kan. 1263);

- we wszystkich ważniejszych sprawach dotyczących życia chrześcijańskiego wiernych i zarządzania diecezją (Apostolorum Successores, nr 183) ${ }^{12}$.

Biskup jako głowa prezbiterium przewodniczy Radzie kapłańskiej i dlatego nie może ona nigdy działać bez jego zgody lub przeciw niemu. Do biskupa należy też decyzja o publikacji tego, co było przedmiotem obrad (kan. 500) ${ }^{13}$.

Kodeks postanawia, że Rada kapłańska ma być senatem reprezentującym całe prezbiterium Kościoła partykularnego i powinno składać się z trzech kategorii członków: z wyboru, z urzędu i nominacji. Konferencja Episkopatu Polski doprecyzowała prawo powszechne i postanowiła, że w Polsce Rada kapłańska winna liczyć od 15 do 40 kapłanów. Połowa jej członków ma pochodzić z wyboru dokonanego przez całe prezbiterium diecezji. Co najmniej połowę wybranych powinni stanowić proboszczowie. Z urzędu do Rady wchodzą: biskup koadiutor, biskupi pomocniczy, wikariusze generalni, kapłani kierujący wydziałami duszpasterstwa w diecezji, rektor wyższego seminarium duchownego i przewodniczący kapituły katedralnej. Pozostali członkowie Rady kapłańskiej pochodzą z nominacji biskupa, który może ich powołać, ale nie ma takiego obowiązku ${ }^{14}$.

Konferencja Episkopatu Polski postanowiła, że kadencja członków Rady kapłańskiej w Polsce będzie trwała pięć lat. Ustępujący członek Rady może być ponownie wybrany lub mianowany, nie powinien jednak w niej pozostawać bez przerwy dłużej niż przez dwie kadencje. W przypadku śmierci członka Rady, jego rezygnacji przyjętej przez biskupa diecezjalnego lub niemożności wykonywania funkcji w Radzie z przyczyn przewidzianych prawem, należy uzupełnić jej skład ${ }^{15}$.

Reasumując, Rada kapłańska jest wyrazem i narzędziem współpracy i dialogu prezbiterium z biskupem diecezjalnym. Sobór niewiele powiedział na temat nowego organu. Dokumenty posoborowe wykazały tendencję do powiększania zakresu zadań i kompetencji Rady. Według KPK Rada kapłańska ma wspierać biskupa radami w zarządzaniu diecezją, natomiast biskup powinien chętnie korzystać z tej

12 Do innych zadań Rady kapłańskiej należy: wybór dwóch przedstawicieli Rady na synod prowincjonalny (kan. 433); uczestniczenie wszystkich członków w synodzie diecezjalnym (kan. 463); wybór zespołu proboszczów (kan. 1742 i 1750). T. Rozkrut, Funkcja Rady Kapłańskiej, „Currenda” 2 (1999), s. 283-284.

13 J. Wroceński, Rada Kapłańska według Kodeksu Prawa Kanonicznego, „Prawo Kanoniczne", 1-2 (1993), s. 71-101.

14 M. Sitarz, Kompetencje organów kolegialnych, dz. cyt., s. 69.

15 „Akta Konferencji Episkopatu Polski”, 1 (1998), s. 139. 
pomocy i liczyć się z jej zadaniem. Chodzi zatem o tzw. wzajemny obowiązek. Jeśli ten aspekt współpracy zostanie zagubiony, wówczas Rada kapłańska może podzielić los swej poprzedniczki - Kapituły katedralnej, stając się jakąś elitarną grupą $\mathrm{w}$ prezbiterium diecezji ${ }^{16}$.

\section{RADA KAPŁAŃSKA W DIECEZJI TARNOWSKIEJ - POCZĄTKI I OKRES PASTERZOWANIA BPA JÓZEFA ŻYCIŃSKIEGO}

Po ogólnej analizie norm dotyczących Rady kapłańskiej w Kościele, czas na spojrzenie na ten organ kolegialny z perspektywy Kościoła tarnowskiego.

Rada kapłańska w diecezji tarnowskiej została powołana w 1981 roku. Dekret ustanawiający Radę został opublikowany 8 września 1981 roku $^{17}$. Kilka dni później, bo 29 września ówczesny pasterz diecezji bp Jerzy Ablewicz ogłosił tymczasowy statut Rady kapłańskiej ${ }^{18}$ i regulamin wyborów ${ }^{19}$.

Ustanowienie nowej instytucji doradczej w Kościele tarnowskim zbiegło się w czasie z rozpoczęciem IV Synodu Diecezji Tarnowskiej (1982-1986). Efektem prac Synodu był nowy statut Rady kapłańskiej połączony ze statutem Kolegium konsultorów ${ }^{20}$.

IV Synod Diecezji tarnowskiej przypomina, że diecezjalna Rada kapłańska jest jakby senatem biskupa, czyli zespołem kapłanów reprezentujących całe duchowieństwo diecezji świeckie i zakonne ${ }^{21}$, posiadającym swoje własne statuty ${ }^{22}$.

Bp Ablewicz mówiąc o Radzie kapłańskiej potwierdzał, że ma ona głos doradczy, który jednak w Kościele cieszy się domniemaniem, że wyrasta z budującego na darach Ducha Świętego zmysłu wiary. Jest zatem świadectwem życia chrześcijańskiego i zasługuje na uważny nasłuch oraz na przemyślenie co i jak można wnieść do wspólnoty diecezjalnej. Szczególną rolę odgrywa dla tych, którzy na to życie mogą wpływać ustanawianymi przez siebie prawami i podejmowanymi decyzjami ${ }^{23}$.

W październiku 1988 roku została wyłoniona Rada kapłańska z kadencją do 1993 roku. Jednak została ona przerwana w 1990 roku śmiercią abpa Ablewicza. W skład Rady wchodziło 42 prezbiterów. Siedmiu zostało włączonych do niej

16 Por. J. Wroceński, Pozycja prezbiterium w Kościele partykularnym, w: Kościót partykularny w Kodeksie Jana Pawła II, red. J. Krukowski, M. Sitarz, Lublin 2004, s. 113.

17 J. Ablewicz, Dekret ustanawiajacy radę Kapłańska w Diecezji Tarnowskiej, „Currenda” 131 (1981), s. 234.

18 J. Ablewicz, Statut, „Currenda” 131 (1981), s. 230-231.

19 J. Ablewicz, Regulamin wyborów, „Currenda”, 131 (1981), s. 231-233.

20 Statut Rady Kapłańskiej i Kolegium Konsultorów, w: IV Synod Diecezji Tarnowskiej (dalej: IV SDT), Tarnów 1986, s. 297-299.

21 Por. IV SDT, stat. $330 \S 1$.

22 Por. IV SDT, stat. $331 \S 2$.

23 Por. J. Ablewicz, Rada kapłańska Diecezji Tarnowskiej. Wstęp, w: Akta Diecezji Tarnowskiej, Rada kapłańska 1967-1985, OG. I-10. 
z urzędu, dwudziestu jeden z wyboru i czternastu z nominacji. Do wybranych należało dwunastu proboszczów, sześciu wikariuszy, dwóch emerytów i przedstawiciel Seminarium Duchownego. Pośród członków nominowanych znajdowało się jedenastu proboszczów, profesor Seminarium Duchownego, pracownik Kurii Diecezjalnej i przedstawiciel duchowieństwa zakonnego ${ }^{24}$.

W roku 1990, za pasterzowania bpa Józefa Życińskiego została wybrana czwarta Rada kapłańska z kadencją do 1995 roku ${ }^{25}$. Do nowej Rady weszło 40 kapłanów: siedmiu z urzędu, dwudziestu jeden z wyboru i dwunastu z nominacji. Pośród wybranych było dwunastu proboszczów, sześciu wikariuszy, dwóch emerytów i wikariusz biskup do spraw zakonnych. Wśród nominowanych znalazło się sześciu proboszczów, dwóch profesorów Seminarium Duchownego, wikariusz, emeryt, rektor i katecheta parafialny ${ }^{26}$. Później powołano do Rady jeszcze jednego proboszcza, a następnie z potrzeby przewidzianej w nowym statucie (art. 4, 2), skład ten został uzupełniony o superiora Kongregacji Oratorium św. Filipa Neri w Tarnowie i o jednego proboszcza ${ }^{27}$.

Wybory z 1990 roku odbyły się według regulaminu wyborów z tego samego roku. Okręgi wyborcze zostały podzielne w następujący sposób: 1-Tarnów Centrum i księża z Domu Emeryta (ul. Starodąbrowska), 2-Baranów Sandomierski i Mielec Południe, 3-Biecz i Tuchów, 4-Bobowa i Gorlice Północ, 5-Bochnia i Uście Solne, 6-Brzesko i Wojnicz, 7-Czchów i Lipnica Murowana, 8-Dąbrowa Tarnowska i Radłów, 9-Dębica Wschód i Ropczyce, 10-Dębica Zachód i Pilzno, 11-Gorlice Południe i Grybów, 12-Kolbuszowa i Sędziszów Małopolski, 13-Krościenko i Łącko, 14-Krynica i Piwniczna, 15-Limanowa i Tymbark, 16-Mielec Północ i Szczucin, 17-Nowy Sącz Południe i Stary Sącz, 18-Nowy Sącz Północ i Ujanowice, 19-Radomyśl Wielki i Tarnów Wschód, 20-Tarnów Zachód i Zakliczyn oraz księża z nowego Domu Emerytów, 21-Kuria Diecezjalna i Seminarium Duchowne ${ }^{28}$.

Wybory miały się zakończyć w nieprzekraczanym terminie do 22 listopada 1990 roku. Okręg wyborcze od 1-8 wybierały kandydatów spośród wikariuszów i emerytów, zaś okręgi od 9-20 wybierały członków spośród proboszczów. Okręg zaś nr 21 wybierał spośród kapłanów zatrudnionych w Kurii Diecezjalnej i Seminarium Duchownym.

24 Skład Rady Kapłańskiej Diecezji Tarnowskiej (1988-1993), „Currenda”, 138 (1988), s. 597 598. Pisma zatwierdzające nowych członków na najbliższe pięciolecie, zob. Akta Kurii Diecezji Tarnowskiej, (dalej: AKDT) Rada kapłańska 1986-1996, L. dz. OF. I-3/208/88.

25 J. Życiński, Dekret zarzadzajacy wybory do Rady kapłańskiej Diecezji Tarnowskiej w 1990 roku, w: AKDT, Rada Kapłańska 1986-1986, L. dz. OF. I-3/354/90.

26 Skład Rady kapłańskiej Diecezji Tarnowskiej (1990-1995), „Currenda”, 140 (1990), s. 674 675. Pisma powołujące nowych członków Rady Kapłańskiej, zob. AKDT, Rada kapłańska 19861996, L. dz. OF. I-3/375/90.

27 Skład Rady Kapłańskiej Diecezji Tarnowskiej, „Currenda” 4 (1993), s. 544. Pisma zatwierdzające nowych członków, zob. AKDT, Rada Kaptańska 1986-1996, L. dz: OF. I-3/190/93.

${ }_{28}$ Okręgi wyborcze i komisje w wyborach do Rady Kapłańskiej Diecezji Tarnowskiej w 1990, w: AKDT, Rada Kapłańska 1986-1996, L. dz. OF. I-3. 
W wyborach z 1995 roku ustanowiono następujące okręgi wyborcze: 1-Tarnów Centrum i księża z Domu Emeryta (ul. Starodąbrowska), 2-Nowy Sącz Północ, 3-Bochnia, 4-Mielec Południe i Mielec Północ, 5-Dąbrowa Tarnowska i Szczucin, 6-Radłów i Uście Solne, 7-Ołpiny i Tuchów, 8-Bobowa, Ciężkowice i Łużna, 9-Brzesko i Wojnicz, 10- Czchów i Lipnica Murowana, 11-Dębica Wschód i Pustków Osiedle, 12-Dębica Zachód i Pilzno, 13-Grybów i Ujanowice, 14-Krościenko i Łącko, 15-Krynica i Piwniczna, 16-Limanowa i Tymbark, 17-Nowy Sącz Południe i Stary Sącz, 18-Radomyśl Wielki i Tarnów Wschód, 19-Tarnów Zachód, Zakliczyn oraz kapłani z Domu Księży Emerytów (ul. Pszenna 7), 20-Kuria Diecezjalna i Seminarium Duchowne ${ }^{29}$.

Jak wynika z powyższych analiz za czasów pasterzowania diecezją tarnowską przez bpa Józefa Życińskiego mamy do czynienia z dwiema kadencjami rady kapłańskiej (jednej pełnej: 1990-1995, a drugiej dwuletniej: 1995-1997). Poniżej przejdę do omówienia konkretnych zagadnień poruszanych w czasie dwóch kadencji Rady w latach 1990-1997.

\section{ZAGADNIENIA PORUSZANE NA SPOTKANIACH RADY KAPŁAŃSKIEJ POD PRZEWODNICTWEM BPA JÓZEFA ŻYCIŃSKIEGO}

Fundamentalnym zadaniem Rady kapłańskiej jest wspieranie biskupa diecezjalnego w zarządzaniu diecezją tak, by możliwie jak najbardziej pomnażało się dobro duchowe wiernych. Realizuje się to przede wszystkim przez udzielania skutecznych rad we wszystkich ważniejszych sprawach diecezjalnych. Dlatego zostanie tu przedstawiona problematyka, jaka była podejmowana na spotkaniach Rady kapłańskiej diecezji tarnowskiej na swoich spotkaniach pod przewodnictwem bpa Józefa Życińskiego.

W latach 1990-1997 odbyło się dwanaście spotkań Rady kapłańskiej diecezji tarnowskiej.

\section{Sprawy dotyczące życia i posługi kapłanów diecezji tarnowskiej}

W dniu 15 grudnia 1990 roku na pierwszej sesji nowo wybranej Rady kapłańskiej jedną z poruszanych kwestii była sprawa wyjazdów księży za granicę. Bp Józef Życiński wyróżnił dwie kategorie kapłanów, którzy chcą wyjechać za granicę. Pierwsza obejmuje tych, którzy chcą jechać na misje, a druga tych, którzy chcą jechać do strefy dolarowej. By jednak móc wyjechać do tej drugiej należało spełnić dwa warunki: mieć pracę w diecezji przez okres nie mniejszy niż dziesięć lat oraz wykazać się dobrą znajomością języka używanego w kraju wyjazdu, składając zeń

29 Okręgi wyborcze i komisje w wyborach do Rady Kapłańskiej Diecezji Tarnowskiej w 1995, w: AKDT, Rada Kaptańska 1986-1996, L. dz. OF. I-3. 
specjalny egzamin. Na tym samym spotkaniu Rada kapłańska opowiedziała się jednogłośnie za ożywieniem ducha misyjnego diecezji i za udzieleniem pomocy tym, którzy pragną poświęcić się temu dziełu ${ }^{30}$.

Na spotkaniu Rady kapłańskiej dnia 13 kwietnia 1991 roku podano informację, że jest już gotowa ekipa kapłanów na placówki misyjno-zagraniczne: ks. M. Kądzielawa do Republiki Południowej Afryki, ks. H. Osora i ks. A. Rams do Związku Socjalistycznych Republik Radzieckich, ks. J. Wal do Peru, ks. Szmist i ks. Kopacz o Żytomierza ${ }^{31}$.

W dniu 27 listopada 1993 roku bp Życiński przedmiotem obrad Rady uczynił status kapłanów, którzy nie ukończyli jeszcze 75 roku życia, a nie dysponują już pełnią sił potrzebnych do skutecznego kierowania parafią. Po uwzględnieniu możliwości różnych rozwiązań, Rada kapłańska przyjęła wniosek, aby zgodnie z dotychczasowymi zasadami, kapłani, którzy ukończyli 70 lat przesyłali na ręce biskupa diecezjalnego list wyrażający gotowość rezygnacji z administrowania parafią w chwili, gdy zostanie to uznane za potrzebne. List taki - jak zauważył bp Życiński - byłby wyrazem psychicznej akomodacji do nowych warunków, uwzględniających trudności narzucone przez wiek. W sytuacjach, gdy ukończenie 70 roku życia nie utrudnia jeszcze w sposób istotny prowadzonych działań duszpasterskich, kapłani sprawowaliby nadal swe obowiązki aż do 75 roku życia. W sytuacjach, gdy racje duszpasterskie przemawiałyby za przyjęciem rezygnacji, przechodzący na emeryturę prezbiter miałby możliwość dalszego pozostania w parafii i mógłby pomagać w miarę swoich możliwości. Przyjęta decyzja Rady kapłańskiej, przy jednym głosie wstrzymującym się, weszła w praktykę od 1 lutego 1994 roku $^{32}$.

2. Uświęcenie i religijna formacja wiernych świeckich

Bp Życiński bardzo dużo uwagi w swej posłudze pasterskiej w diecezji tarnowskiej poświęcał osobom świeckim. Tematyka ta znalazła także swoje odbicie na spotkaniach Rady kapłańskiej. Na posiedzeniu Rady 13 kwietnia 1991 roku padła propozycja powołania Diecezjalnej Rady Świeckich. Poproszono księży dziekanów o wyznaczenie z każdego dekanatu po trzech przedstawicieli do tejże Rady. Uczestnicy posiedzenia stwierdzili, że najbardziej interesować ich będzie troska o życie eucharystyczne w diecezji i posługa świeckich przygotowanych do rozdawania Komunii Świętej ${ }^{33}$.

30 Sprawozdanie z posiedzenia Rady kapłańskiej z 15.12.1990, w: AKDT, Rada Kapłańska 1986-1996, L. dz. OF. I-3/90.

31 Sprawozdanie z posiedzenia Rady kapłańskiej z 13.04.1991, w: AKDT, Rada Kapłańska 1986-1996, L. dz. OF. I-3/91.

32 Por. J. Życiński, List Biskupa Tarnowskiego do Kapłanów Diecezji Tarnowskiej, „Currenda", 1 (1994), s. 34-35.

33 Sprawozdanie z posiedzenia Rady kapłańskiej z 13.04.1991, w: AKDT, Rada Kapłańska 1986-1996, L. dz. OF. I-3/91. 
Bp Józef Gucwa podkreślił jak ważna jest kultura osobista księży w odniesieniu do świeckich. Zaproponował, aby Duszpasterska Rada Świeckich wzięła na siebie przynajmniej część odpowiedzialności za klimat wzajemnych odniesień pomiędzy świeckimi a duchownymi. Ks. Stanisław Czachor nawiązując do wypowiedzi biskupa stwierdził, że świeccy nie zawsze są w porządku wobec księży ${ }^{34}$.

\section{Przeznaczanie ofiar składanych z racji wykonywania zadań parafialnych i wynagrodzenia duchownych}

15 grudnia 1990 roku na spotkaniu Rady kapłańskiej zajmowano się między innymi sprawą utrzymania księży. Wśród propozycji znalazła się kwestia reorganizacji struktur wzajemnej pomocy duchowieństwa. Postanowiono, że $\mathrm{Ca}$ ritas sacerdotalis powinna uzyskać dodatkowe fundusze $\mathrm{z}$ opodatkowania dochodów kolędowych księży. Ożywiona dyskusja uwypukliła przede wszystkim konieczność budowania wspólnoty kapłańskiej oraz sprawiedliwszego podziału dochodów tak w poszczególnych parafiach jak i w diecezji. Prawie jednogłośnie przyjęto wniosek dziesięcioprocentowego opodatkowania dochodów kolędowych kapłanów na rzecz ogólnodiecezjalnego funduszu kapłańskiego. Miało ono dotyczyć wszystkich kapłanów pracujących w parafiach powyżej tysiąca wiernych. Jest to zobowiązanie sumienia. Wpłat należało dokonywać do 15 lutego każdego roku. W czasie posiedzenia Rady rozważono także różne modele funkcjonowania wspólnoty dochodów oraz ich podziału między kapłanami. Pod przewodnictwem bpa Życińskiego Rada kapłańska postanowiła zmodyfikować nieco postanowienia IV Synodu Diecezji Tarnowskiej w tej materii, i dlatego po głosowaniu, przyjęła wniosek o wprowadzenie w życie diecezji tarnowskiej następującej zasady: w diecezji obowiązuje całkowita wspólnota podziału dochodów i utrzymania, z dopuszczeniem jednak wspólnoty częściowej, ale zawsze po uprzednim obustronnym potwierdzeniu tej ostatniej. W kwestiach spornych rozstrzygnięcie należy do Kurii Diecezjalnej ${ }^{35}$.

Na kolejnej sesji Rady kapłańskiej 13 kwietnia 1991 roku przyjęto poprawkę do poprzedniego protokołu. Przegłosowano, iż można dziesięć procent pieniędzy z kolędy przeznaczyć na budowę kościoła, pod warunkiem, że kościół ten jest w stanie surowym i wyrazi na to zgodę Kuria Diecezjalna. Na tym samym spotkaniu bp Gucwa poinformował o konieczności przeredagowania statutu Caritas sacerdotalis, który w przyszłości powinien uwzględniać renty i emerytury państwowe oraz

34 Tamże. Tematyce świeckich było poświęcone spotkanie Rady kapłańskiej 10 kwietnia 1995 roku, gdzie poruszono sprawy formacji i katechezy dorosłych, a także zagadnienie dotyczące Akcji Katolickiej. Sprawozdanie z posiedzenia Rady kapłańskiej z 10.04.1995, w: AKDT, Rada Kapłańska 1986-1996, L. dz. OF. I-3/317/95.

35 Sprawozdanie z posiedzenia Rady kapłańskiej z 15.12.1990, w: AKDT, Rada Kapłańska 1986-1996, L. dz. OF. I-3/90. 
wszystkie inne ważne i naglące potrzeby księży. Zaproponowano, by pomoc była regulowana intencjami i stypendiami mszalnymi rozdzielanymi przez Kurię ${ }^{36}$.

\section{Inne sprawy mające na uwadze dobro Kościoła tarnowskiego}

Na pierwszym spotkaniu Rady kapłańskiej pod przewodnictwem bpa Józefa Życińskiego, pasterz Kościoła tarnowskiego poinformował o powstaniu kurialnej kawiarni „Betania” oraz diecezjalnego wydawnictwa i sklepu „Biblos”. Poruszono także problem finansowego utrzymania sióstr zakonnych. Na podstawie ankiety został zarysowany wstydliwy obraz niewłaściwego wynagrodzenia sióstr, gdyż w znacznej części parafii, siostry nie są opłacane w ogóle lub w sposób śmiesznie mały. W dyskusji została podniesiona sprawa aktualizacji umów o pracę powołując się na podstawowe poczucie sprawiedliwości w wynagradzaniu. Podsumowaniem dyskusji była wiadomość o mianowaniu przez biskupa tarnowskiego wikariusza biskupiego do spraw zakonnych - ks. dr W. Kostrzewy - z prawami uregulowania prawnego wszystkich spraw ${ }^{37}$.

Na spotkaniu 15.12.1990 roku poruszono kwestię utrzymania organistów i kościelnych. Ks. A. Zając przedstawiając sprawy wynagrodzenia organistów ograniczył się do przedstawienia zaleceń i rozporządzeń synodalnych. Wysunął także kilka sugestii, m.in. by wprowadzić rozróżnienie w wysokości pensji dla fachowych organistów i tych, którzy są tylko po kursach. Zaproponował, by średnia płaca miesięczna organisty na pełnym etacie odpowiadała zarobkom nauczyciela religii. Ofiary wiernych dla organisty miały być dodatkiem. Wszelkie sposoby wynagradzania organistów powinny być określone ważną umową o pracę. Ks. K. Szwarga przedstawił różne sposoby wynagradzania kościelnych, które w dużej mierze były podobne do finansowania organistów i regulowane przepisami synodalnymi. Prelegent podkreślił, że w większych parafiach powraca zwyczaj, że sami wierni okazjonalnie opłacają kościelnych. Wielu kościelnych wykonuje także inne zajęcia poza kościelne i dlatego nie można ich zatrudniać w pełnym wymiarze godzin. Powinni być jednak sprawiedliwie wynagradzani za wykonaną pracę ${ }^{38}$.

W 1991 roku na spotkaniu Rady kapłańskiej poruszono sprawę Rady Gospodarczej w parafii. Ks. K. Kos wyraził opinię, że Rady Gospodarcze są czymś nieuniknionym, zaś ks. P. Gajda zwrócił uwagę na potrzebę napisania dwóch oddzielnych statutów, dla Parafialnej Rady Duszpasterskiej oraz dla Rady Gospodarczej ${ }^{39}$.

36 Sprawozdanie z posiedzenia Rady kapłańskiej z 13.04.1991, w: AKDT, Rada Kapłańska 1986-1996, L. dz. OF. I-3/91.

37 Sprawozdanie z posiedzenia Rady kaptańskiej z 15.12.1990, w: AKDT, Rada Kapłańska 1986-1996, L. dz. OF. I-3/90.

38 Tamże.

39 Sprawozdanie z posiedzenia Rady kapłańskiej z 13.04.1991, w: AKDT, Rada Kapłańska 1986-1996, L. dz. OF. I-3/91. 
Rada kapłańska jest organem informacyjnym, opiniotwórczym w Kościele. Jest bardzo potrzebna dla duchowieństwa i wiernym świeckim dla prowadzenia dzieła ewangelizacji. Wychodząc z takich właśnie założeń bp Józef Życiński w swojej posłudze w Kościele tarnowskim w latach 1990-1997 często korzystał z opinii Rady. Czynił to wtedy, kiedy wymagało to prawo powszechne, ale także przy rozwiązywaniu problemów dotyczących życia i posługi kapłanów, jak również w sprawach duszpasterskich. Bp Życiński traktował Radę kapłańską jako forum dialogu i współpracy z całym prezbiterium diecezji tarnowskiej.

System podejmowania i rozwiązywania spraw istotnych dla diecezji tarnowskiej za czasów pasterzowania bpa Życińskiego w oparciu o konsultacje i sugestie odpowiadał stanowi świadomości ukształtowanemu przez Sobór Watykański II, który dotyczył Rady kapłańskiej.

\section{THE WORK OF THE TARNOW DIOCESE PRESBYTERAL COUNCIL UNDER BISHOP ZYCINSKI BETWEEN 1990 AND 1997}

\section{Summary}

The Code of Canon Law gives the definition of a presbyteral council and declares:,,In each diocese a presbyteral council is to be established, that is, a group of priests which, representing the presbyterium, is to be like a senate of the bishop and which assists the bishop in the governance of the diocese according to the norm of law to promote as much as possible the pastoral good of the portion of the people of God entrusted to him".

The Fourth Synod of Tarnow Diocese reminds that a Diocese Presbyteral Council is as if the bishop's senate with its own statues; a team of priests representing all clergy of the diocese, both diocesan and from religious orders.

During the time when the diocese was led by bishop Życiński, there have been two terms of the Presbyteral Council with elections in 1990 and 1995. The article analyses the topics debated over by the Presbyteral Council between 1990 and 1997. Some of the following items were on the Council's agenda: priests' retirement age, spiritual formation of the lay members of the church, missions.

Keywords

bishop, bishop Zycinski, presbyteral council, Tarnow diocese 